\begin{tabular}{|l|l|}
\hline 2. To: (Receiving Organization) & $\begin{array}{l}\text { 3. From: coriginating Organization) } \\
\text { SA\&NE }\end{array}$ \\
\hline TWRS SAR ENGINEERING & $\begin{array}{l}\text { 6. Design Authority/ Design Agent/Cog. } \\
\text { Engr.: }\end{array}$ \\
$8 M 400$ & L. F. WOJDAC \\
\hline
\end{tabular}

8. Originator Remarks:

The attached document is submitted as information

4. Related EDT No.:

7. Purchase Order No.:

$$
N / A
$$

9. Equip./Component No.:

N/A

10. Systen/Bldg./Facility: TWRS

11. Receiver Remarks: 11A. Design Baseline Document? [] Yes [X] No For Information $\mathrm{N} / \mathrm{A}$

12. Major Assm. Dwg. No.:

13. Permit/Permit Application No.: $\mathrm{N} / \mathrm{A}$

14. Required Response Date: 9/20/96

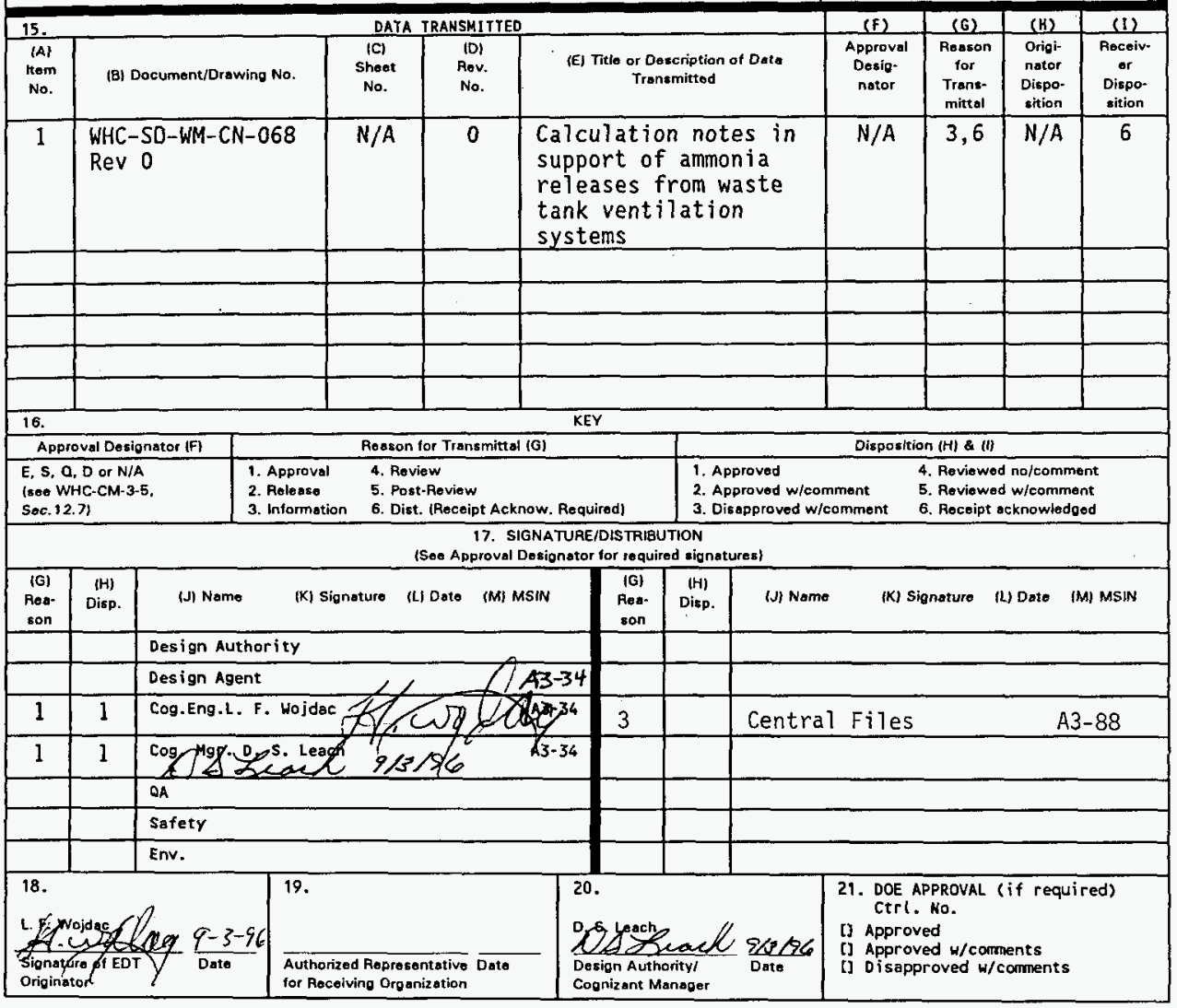




\title{
Calculation Notes in Support of Ammonia Releases from Waste Tank Ventilation Systems
}

\author{
L. F. Wojdac \\ Westinghouse Hanford Co., Richland, WA 99352 \\ U.S. Department of Energy Contract DE-AC06-87RL10930 \\ EDT/ECN: 619205 \\ UC: 2000 \\ Org Code: 8M400 \\ Charge Code: NB602 \\ B\&R Code: EW3130010 \\ Total Pages: 11
}

Key Words: Diffusion, toxic, TWRS, dose

Abstract: Ammonia is generated in waste tanks via the degradation of nitrogen compounds. The ammonia is released from the liquids by a mechanism which is dependent on temperature, $\mathrm{pH}$, ionic strength and ammonia concentration. The release of ammonia to the environment occurs via diffusion of ammonia through a stagnant air mass and into the ventilation system.

TRADEMARK DISCLAIMER. Reference herein to any specific commercial product, process, or service by trade name, trademark, manufacturer, or otherwise, does not necessarily constitute or imply its endorsement, recommendation, or favoring by the United States Government or any agency thereof or its contractors or subcontractors.

Printed in the United stares of America. To obtain copies of this docunent, contact: WHC/BCS Document Control Services, P.0. Box 1970, Mailstop H6-08, Richtand WA 99352, Phone (509) 372-2420; Fax (509) 376-4989.
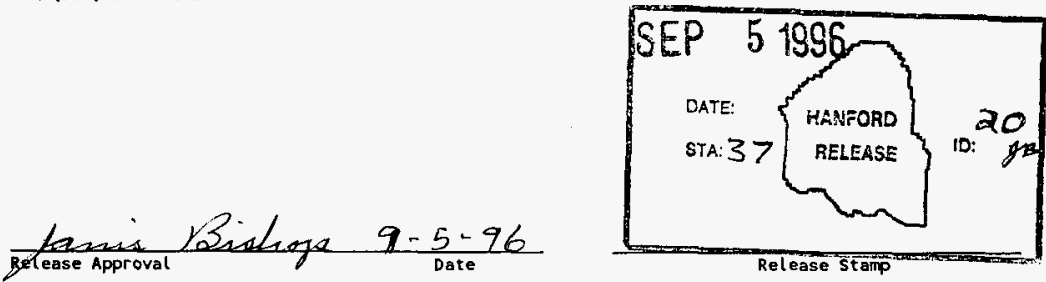

\section{Approved for Public Release}


Diffusion of Ammonia into The Head Spaces for both Single and Double Shelled Tanks

Purpose: This document reports the results of analyses designed to predict the concentration of ammonia in forced ventilation exhaust gases under normal operating conditions. A11 data and tank specific information was obtained from document number WHC-SD-BI0-001 REV A.

Methodology: Actively vented single and double shell tanks are vented in a manner such that ventilation flow enters the tank through ventilation headers and exits through an exhaust manifold which is maintained at a reduced

pressure. Stream lines for this type of flow typically are smooth and are not highly turbulent with the possible exception of entrance and outlet effects. Assuming nonturbulent flow, diffusion of ammonia from the surface of the tank waste can be represented by a diffusion cell model.

The basis for this analysis is the Arnold diffusion cell. The diffusion height is defined to be the space between the top of the waste surface and the top of the tank. Table I lists the critical tank dimensions for the single shell tanks.

TABLE 1

TABLE OF VARIABLES

(single shell tanks)

\begin{tabular}{|c|c|c|c|}
\hline Diameter (m) & Total Height $(\mathrm{m})$ & $\begin{array}{l}\text { Depth of } \\
\text { Liquid(m) }\end{array}$ & $\begin{array}{c}\text { Head Space Height } \\
\text { (diffusion length) }\end{array}$ \\
\hline $23 \mathrm{~m}$ & $11.3 \mathrm{~m}$ & $\begin{array}{c}5.2 \mathrm{~m} \\
\text { (nominal } \\
\text { operation) }\end{array}$ & $\begin{array}{c}6.1 \mathrm{~m} \\
\text { (nominal operation) }\end{array}$ \\
\hline $23 \mathrm{~m}$ & $11.3 \mathrm{~m}$ & $\begin{array}{c}9.4 \mathrm{~m} \\
\text { (Maximum } \\
\text { operation) }\end{array}$ & (Maximum operation) \\
\hline & & & \\
\hline
\end{tabular}


Table 2 lists the critical tank dimensions for the double shell tanks. Data on the heights and nominal capacities for the double shell tanks were taken from Table 2-20 of document WHC-SD-WM-BI0-001, The highest and lowest values were used to calculate the upper and lower bounds for the nominal and maximum capacity cases.

TABLE 2

TABLE OF VARIABLES

(double shell tanks)

\begin{tabular}{|c|c|c|c|}
\hline Diameter (m) & Total Height (m) & $\begin{array}{l}\text { Depth of } \\
\text { Liquid(m) }\end{array}$ & $\begin{array}{l}\text { Head Space Height } \\
\text { (diffusion length) }\end{array}$ \\
\hline $23 \mathrm{~m}$ & $14.25 \mathrm{~m}$ & $\begin{array}{l}9.1 \mathrm{~m} \\
\text { (nominal low } \\
\text { operation) }\end{array}$ & $\begin{array}{c}5.15 \mathrm{~m} \\
\text { (nominal operation) }\end{array}$ \\
\hline $23 \mathrm{~m}$ & $14.25 \mathrm{~m}$ & $\begin{array}{l}\quad 10.6 \mathrm{~m} \\
\text { (nominal } \\
\text { high } \\
\text { operation) }\end{array}$ & $\begin{array}{c}3.65 \mathrm{~m} \\
\text { (nominal operation) }\end{array}$ \\
\hline $23 \mathrm{~m}$ & $14.25 \mathrm{~m}$ & $\begin{array}{l}9.2 \mathrm{~m} \\
\text { (maximum low } \\
\text { operation) }\end{array}$ & $\begin{array}{l}5.05 \mathrm{~m} \\
\text { (maximum operation) }\end{array}$ \\
\hline $23 \mathrm{~m}$ & $14.25 \mathrm{~m}$ & $\begin{array}{l}\quad 10.7 \mathrm{~m} \\
\text { (maximum } \\
\text { high } \\
\text { operation) }\end{array}$ & $\begin{array}{c}3.55 \mathrm{~m} \\
\text { (maximum operation) }\end{array}$ \\
\hline & & & \\
\hline
\end{tabular}

\section{Background:}

The basic relation describing the unidirectional diffusion of a gas describes the molar flux relative to a molar-average velocity, $J_{A}$. An empirical relation, which is the basis for all, one directional analyses is Fick's law of diffusion (Fick's First Law). For isothermal, isobaric conditions, the Fick rate equation can be stated as:

$$
J_{A, z}=-D_{A B} \frac{d C_{A}}{d z}
$$

where $J_{A, z}$ is the molar average flux in the $z$ direction relative to the molar average velocity, $D_{A B}$ is the diffusion coefficient and $c_{A}$ is the molar concentration.

For nonisobaric, nonisothermal conditions a more general flux relation was proposed by de Groot ${ }^{1}$. The de Groot relation is stated as: 


$$
\begin{gathered}
\text { WHC-SD-WM-CN-068, Rev. } 0 \\
\text { FIUx }=-\left(\begin{array}{c}
\text { overall } \\
\text { density }
\end{array}\right)\left(\begin{array}{c}
\text { diffusion } \\
\text { coefficient }
\end{array}\right)\left(\begin{array}{c}
\text { concentration } \\
\text { gradient }
\end{array}\right)
\end{gathered}
$$

expressed in mathematical terms

$$
J_{A}=-c D_{A B} \frac{d y_{A}}{d z}
$$

where $y_{A}$ is the mole fraction of component $A$.

For a binary system the unidirectional flux of component $A$ in the $z$ direction relative to the molar average flux can be defined as

$$
J_{A, z}=C_{A}\left(V_{A, z}-V_{Z}\right)
$$

where $V_{A, z}$ is the velocity of component $A$ in the $z$ direction and $V_{z}$ is the molar avérage velocity.

Equating equations 3 and 4 yields the expression

$$
\begin{aligned}
J_{A, z} & =c_{A}\left(V_{A, z}-V_{z}\right) \\
& =-c D_{A B} \frac{d y_{A}}{d z}
\end{aligned}
$$

solving for $C_{A} V_{A, z}$ yields

$$
c_{A} V_{A, z}=-c D_{A B} \frac{d y_{A}}{d z}+c_{A} V_{z}
$$

for a binary system the molar average velocity can be expressed as

$$
c_{A} V_{z}=y_{A}\left(C_{A} V_{A, z}+c_{B} V_{B, z}\right)
$$

The molar flux of component $A$ can then be written as

$$
c_{A} v_{A, z}=-c D_{A B} d y_{A} / d z+y_{A}\left(C_{A} v_{A, z}+c_{B} v_{B, z}\right)
$$

considering the diffusion relative to a stationary set of axes define and

$$
\mathrm{N}_{\mathrm{A}}=\mathrm{C}_{\mathrm{A}} \mathrm{v}_{\mathrm{A}}
$$

$$
N_{B}=c_{B} v_{B}
$$


WHC-SD-WM-CN-068, Rev. 0

The molar diffusion expression can then be written as

$$
N_{A, z}=-C D_{A B} \frac{d y_{A}}{d z}+y_{A}\left(N_{A, z}+N_{B, z}\right)
$$

For diffusion into a stagnant system, $N_{B, z}$ is taken to be 0 . Rearranging equation 9 and solving for $N_{A, z}$ the defining equation for the molar diffusion of a gas $A$ into $B$ (air) is

$$
N_{A, z}=-C \frac{D_{A B}}{1-y_{A}} \frac{d y_{A}}{d z}
$$

integrating

$$
N_{A, z} \int_{z_{1}}^{z_{2}} d z=c D_{A, z} \int_{Y_{A z}}^{y_{A B}} \frac{d y_{A}}{1-y_{A}}
$$

evaluated at the limits

$$
N_{A, z}=\frac{C D_{A B}}{\left(z_{2}-z_{1}\right)} \ln \frac{\left(1-y_{A z}\right)}{\left(1-y_{A 1}\right)}
$$

Where $y_{A 1}$ and $y_{A 2}$ are mole fractions of component $A$ at points $z_{1}$ and $z_{2}$ respectively. For a two component system, component $B$ can be expressed in terms of component $A$ as:

$$
\begin{aligned}
& 1-y_{A 1}=y_{B 1} \\
& 1-y_{A 2}=y_{B 2}
\end{aligned}
$$

so that the log term can be expressed in terms of component B (air) as

$$
\ln \frac{\left(1-y_{A 2}\right)}{\left(1-y_{A 1}\right)}=\ln \frac{y_{B 2}}{y_{B 1}}
$$

The log- mean average concentration is defined by the relation 


$$
\begin{aligned}
& \text { WHC-SD-WM-CN-068, Rev. } 0 \\
& y_{B, I m}=\frac{y_{B 2}-y_{B I}}{\ln \left(\frac{y_{B 2}}{y_{B I}}\right)} \quad \text { (14) }
\end{aligned}
$$

the term $\ln \left(\mathrm{y}_{\mathrm{B} 2} / \mathrm{y}_{\mathrm{B} 1}\right)$ then can be expressed as

$$
\ln \left(\frac{y_{B 2}}{y_{B 1}}\right)=\frac{y_{B 2}-y_{B 1}}{y_{B, 1 m}}
$$

Equation 15 can be stated in terms of the partial pressure of component $A$ $\left(p_{A}\right)$, component $B\left(p_{B}\right)$ and the system pressure by making the following substitutions:

$$
\begin{aligned}
& y_{A}=p_{A} / P \\
& y_{B}=p_{B} / P \\
& c=n / V \\
& n=P V / R T
\end{aligned}
$$

On making the above substitutions, the system pressure cancels out of the partial pressure terms and the expression for the steady state diffusion (molar flux), of component $A$ into a stagnant gas (B) reduces to

$$
N_{A, z}=\frac{D_{A B} P}{R T\left(z_{2}-z_{1}\right)} \frac{\left(p_{A 1}-p_{A Z}\right)}{p_{B_{1}, 1 m}}
$$

$z_{2}-z_{1}$ is the diffusion length, which in this analysis is taken to be the length of the vapor space above the liquid. Pressure $p_{A 1}$ is the equilibrium vapor pressure of component $A$ at the liquid/air interface and $P$ is the system pressure, taken to be one atmosphere in this analysis. The values of $p_{B 1}$ and $\mathrm{p}_{\beta_{2}}$ are the partial pressures of air in this analysis and are obtained from the ammonia values $p_{A}$ using the relation

$p_{B 1}=1-p_{A 1}$ where the partial pressures are expressed in atmospheres. The value for $p_{B 2}$ is obtained in a similar manner.

The diffusion constant, $D_{A B}$ has units of $\mathrm{cm}^{2} / \mathrm{sec}$ and was calculated based on an empirical estimation method presented by Fuller, Schettler and Giddings ${ }^{2}$.

$\dot{M}_{A}$ and $M_{B}$ are the molecular weights of ammonia and air respectively, $P$ is the system pressure in atmospheres and $T$ is the temperature in ${ }^{\circ} \mathrm{K}$ 
WHC-SD-WM-CN-068, Rev. 0

$$
D_{A B}=\frac{10^{-3} T^{1.75}\left[\frac{\left(M_{A}+M_{B}\right)}{M_{A} M_{B}}\right]^{1 / 2}}{P\left[\left(\sum v\right)_{A}^{1 / 3}+\left(\sum v\right)_{B}^{1 / 3}\right]^{2}}
$$

The terms $(\Sigma v)_{A}$ and $(\Sigma v)_{B}$ are defined as diffusion volumes and were obtained from Table $3-342$ of Perry's Chemical Engineers Handbook ${ }^{3}$. The values for air and ammonia are listed below

$$
\begin{aligned}
& (\Sigma \mathrm{v})_{A}=14.9(\mathrm{NH} 3) \\
& (\Sigma \mathrm{v})_{B}=20.1 \text { (air) }
\end{aligned}
$$

For $\mathrm{T}=372^{\circ} \mathrm{K}\left(210^{\circ} \mathrm{F}\right)$ and one atmosphere pressure the diffusion constant of ammonia in air is

$$
\begin{gathered}
D_{A B}=\frac{10^{-3} 372^{1.75}\left[\frac{(17.03+28.84)}{(17.03)(28.84)}\right]^{1 / 2}}{\text { (1) }\left[(14.9)^{1 / 3}+(20.1)^{1 / 3}\right]^{2}} \\
D_{A B}=0.3571 \mathrm{~cm}^{2} / \mathrm{sec}
\end{gathered}
$$

\section{System Specific Calculations:}

Assumptions:

The concentration of ammonia in the headspace air was calculated for both the single and double shell tanks. The tank parameters required for the calculations were the diameter and diffusion length, these parameter are listed in tables 1 and 2 of this document.

It is reported in section 5.3.3.9.1 of document number WHC-SD-WM-BI0-001 that the equilibrium vapor concentration of ammonia in waste tanks is $0.4 \mathrm{mg} / \mathrm{liter}$ of headspace volume. It is further stated that the concentration of ammonia in the headspace does not change with $\mathrm{pH}$ at $\mathrm{pH}$ 's above 9.27. At a concentration of $0.4 \mathrm{mg} / \mathrm{L}$, the partial pressure of ammonia is $0.00072 \mathrm{Atm}$. at $372{ }^{\circ} \mathrm{K}$.

Calculations:

$$
\begin{gathered}
0.4 \mathrm{mg} / \mathrm{l} * \frac{1}{1000} * g / \mathrm{mg} * \frac{1}{17 g / g-m o l e} * 22.4 \mathrm{l} / \mathrm{g} \text {-mole } * \frac{372}{273} \\
\quad=0.00072 \frac{1 \text { iter } \mathrm{NH}_{3}}{\text { liter headspace volume }}
\end{gathered}
$$

Letting $\mathrm{p}_{\mathrm{A}}=\mathrm{p}_{\mathrm{NH} 3}=0.00072 \mathrm{~atm}$.

$$
p_{B}=1-p_{A}=1-0.00072=0.9993 \mathrm{~atm} .
$$


WHC-SD-WM-CN-068, Rev. 0

$$
\begin{aligned}
& P_{\mathrm{t}} * \frac{V_{N H_{3}}}{V_{\text {tot }}}=p_{N H_{3}} \quad(20) \\
& p_{B \text { Im }}=\frac{1-0.9993}{\ln \left(\frac{1}{0.9993}\right)} \\
& =\frac{0.00072}{\ln 1.0007} \\
& p_{B 2 m}=1.029 \quad \text { (21) } \\
& N_{A z}=\frac{0.357 \frac{\mathrm{cm}^{2}}{\mathrm{sec}}}{(0.08205) \frac{\ell \mathrm{atm}}{{ }^{\circ} \mathrm{K}-\text { mole }}\left(372^{\circ} \mathrm{K}\right)(610 \mathrm{~cm})} * \frac{1 \mathrm{~atm} * 0.00072 \mathrm{~atm}}{1.029 \mathrm{~atm} * 1000 \frac{\mathrm{cm}^{3}}{\mathrm{l}}} \\
& =1.43 \times 10^{-11} \frac{\mathrm{g}-\mathrm{mole}}{\mathrm{cm}^{2} \mathrm{sec}}
\end{aligned}
$$

Using the data from Table 1 (nominal operation):

The molar diffusion will then be

for a surface area of $4.15 \times 10^{6} \mathrm{~cm}^{2}$ the mass release rate of ammonia in the vented headspace air will be

$$
\begin{gathered}
1.43 \times 10^{-11} \frac{\mathrm{g} \text {-mole }}{\mathrm{cm}^{2} \mathrm{sec}} * 4.15 \times 10^{6} \mathrm{~cm}^{2} * 17 \frac{\mathrm{g}}{\mathrm{g} \text {-mole }}=1.01 \times 10^{-3} \frac{\mathrm{g}}{\mathrm{sec}} \\
\left(3.6 \frac{\mathrm{g}}{\mathrm{hr}}\right)
\end{gathered}
$$

All headspace concentrations were calculated in a similar manner, only the diffusion length differed. The results are tabulated in Table 3. 
WHC-SD-WM-CN-068, Rev. 0

TABLE 3

Concentration of Ammonia in the

Headspace for Selected Double Shell and

\begin{tabular}{|c|c|c|c|c|c|}
\hline $\begin{array}{l}\text { Tank } \\
\text { Type }\end{array}$ & $\begin{array}{l}\text { Diameter }(\mathrm{m}) \\
(\mathrm{syrface} \text { area } \\
\left.\mathrm{cm}^{2}\right)\end{array}$ & $\begin{array}{l}\text { Total } \\
\text { Height (m) }\end{array}$ & $\begin{array}{l}\text { Depth of } \\
\text { Liquid (m) }\end{array}$ & $\begin{array}{l}\text { Diffusion Path } \\
\text { Length }(\mathrm{m})\end{array}$ & $\begin{array}{c}\text { Ammonia Release } \\
\text { Rate }(\mathrm{g} / \mathrm{hr})\end{array}$ \\
\hline ss & $4.15^{23} \times 10^{6}$ & 11.3 & 5.2 & 6.1 & 3.6 \\
\hline ss & $4.15 \times 10^{23}$ & 11.3 & 9.4 & 1.9 & 11.6 \\
\hline DS & $4.15^{23} \times 10^{6}$ & 14.25 & 9.1 & 5.15 & 4.3 \\
\hline DS & $4.15 \times 10^{6}$ & 14.25 & 10.6 & 3.65 & 6.0 \\
\hline DS & $4.15^{23} \times 10^{6}$ & 14.25 & 9.2 & 5.05 & 4.4 \\
\hline DS & $4.15 \times 10^{23}$ & 14.25 & 10.7 & 3.55 & 6.2 \\
\hline
\end{tabular}


Turbulent flow considerations:

Because of momentum considerations, the flow across the top of tank is never truly streamlined. The incoming air mass tumbles into the tank for a certain distance before flowing toward the exit port, which is maintained at a reduced pressure. Although it is technically possible to calculate the free volume of a tank that is swept by the incoming air mass the uncertainties in such a calculation would be quite high.

Using engineering judgement, it is reasonable to assume that there is some fraction of the free volume of a waste tank that is stagnant. If it can be assumed that at least one meter of tank atmosphere above the liquid surface is stagnant the maximum release rate of ammonia into the vent gas system for the forced ventilation case is approximately 16 grams per hour per tank for any double or single shell tank.

\section{REFERENCES}

1. S. R. de Groot, Thermodynamics of Irreversible Processes, NorthHoll and, Amsterdam, 1951.

2. E. N. Fuller, P. D. Schettler, and J. C. Giddings, Ind. Eng. Chem. , 58(5), 18 (1966).

3. R. H. Perry, D. W. Green, Perry's Chemical Engineers' Handbook, 6th edition, McGraw-Hill Book Co., 1984.

4. WHC-SD-WM-BIO-001 REV A, Tank Waste Remediation System, "Basis' for Interim Operation", (Draft). 


\section{CHECKLIST FOR TECHNICAL PEER REVIEW}

Document Reviewed: WHC-SD-WM-CN-068 REV 0

Scope of Review: Peer review entire document

$\frac{\text { Yes No NA }}{[][] \text { D] }}$

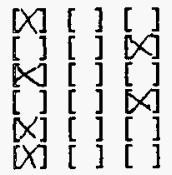

X] [ ] [ ]

X] [ ] [ ]

[X] [ ] [ ]

$\left[\begin{array}{llll}] & {[} & \mathbb{C} & \mathbb{X}\end{array}\right]$

$\infty[$ ] [ ]

国[1]我

$[X][][]$

X] [ ] [ ]

[X] [ ] Review calculations, comments, and/or notes are attached.

[ ] [ ] [ ] Document approved.

Previous reviews complete and cover analysis, up to scope of this review, with no gaps.

Problem completely defined.

Accident scenarios developed in a clear and-logical manner.

Necessary assumptions explicitly stated and supported.

Computer codes and data files documented.

Data used in calculations explicitly stated in document.

Data checked for consistency with original source information as applicable.

Mathematical derivations checked including dimensional consistency of results.

Models appropriate and used within range of validity or use outside range of established validity justified.

Hand calculations checked for errors. Spreadsheet results should be treated exactly the same as hand calculations. Software input correct and consistent with document reviewed. Software output consistent with input and with results reported in document reviewed.

Limits/criteria/guidelines applied to analysis results are appropriate and referenced. Limits/criteria/guidelines checked against references.

Safety margins consistent with good engineering practices.

Conclusions consistent with analytical results and applicable limits.

Results and conclusions address all points required in the problem statement.

Format consistent with appropriate NRC Regulatory Guide or other standards

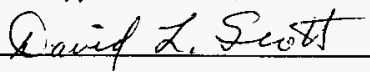

Reviewer (Printed Name and Signature)

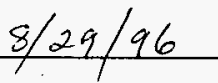

Date

Any notes and/or comments should be attached. 